\author{
Marcin MichalaK \\ https://orcid.org/0000-0003-4434-4051 \\ Uniwersytet Warmińsko-Mazurski w Olsztynie
}

\title{
TAM I Z POWROTEM - AKTUALNE WALORY POZNAWCZE MUZYKI HIPISOWSKIEJ
}

\begin{abstract}
Streszczenie: Celem artykułu jest przegląd twórczości muzycznej określanej „hipisowską” w kontekście jej współczesnych walorów poznawczych. Retrospektywę zespołów, wykonawców i utworów muzycznych poprzedzono krótką charakterystyką amerykańskiego i polskiego ruchu hipisowskiego z lat 60. i 70. XX wieku. Przeglądu wybranych przykładów twórczości muzycznej z tego okresu dokonano pod kątem ich walorów muzycznych, tekstowych, wizualnych (okładki płyt, występy sceniczne), przywołując także sylwetki twórców oraz tło społeczno-kulturowe epoki. W podsumowaniu podjęto próbę przeniesienia wyodrębnionych walorów muzyki hipisowskiej na grunt edukacyjny z odniesieniami do współczesnej edukacji artystycznej, obywatelskiej, a także - pedagogiki krytycznej czy nauczania do twórczości.
\end{abstract}

Słowa kluczowe: muzyka, rock, hipisi, edukacja

\section{WPROWADZENIE}

Lata 60. XX w. to bardzo „gorący” okres. Przez państwa demokracji zachodniej przetacza się bunt młodzieży, mają miejsce strajki na uniwersytetach, manifestacje uliczne, protesty przeciwko wojnie w Wietnamie, walki o prawa obywatelskie Afroamerykanów i mniejszości seksualnych, rozkwita rewolucja seksualna, druga fala feminizmu, pojawiają się pierwsze manifesty ekologiczne (Kurowski 1992; Jarniewicz 2016).

W Polsce, podobnie jak w innych krajach ówczesnego bloku komunistycznego, przemiany te odbijają się początkowo dalekim echem, aby w marcu 1968 roku przybrać postać krótkiego studenckiego prodemokratycznego zrywu - szybko zresztą zduszonego przez milicję i wojsko (Blumsztajn 2018; Osęka 2018). Kilka miesięcy później, w sierpniu 1968 roku, wojska Układu Warszawskiego w wyjątkowo 
krwawy sposób pacyfikują podobny prodemokratyczny zryw w Czechosłowacji, zwany Praską Wiosną (Surosz 2018).

W zachodnim świecie, w połowie dekady, narastający od lat 50 . XX wieku bunt młodzieżowy przeciwko konserwatywnemu pokoleniu rodziców wydaje na świat hipisów. Pojawiają się najpierw w USA, Wielkiej Brytanii, Holandii, a potem także w innych częściach globu, wliczając w to kraje komunistyczne. Około 1967 roku ruch hipisowski zaczyna tworzyć się także w Polsce, gdzie nie ma łatwego żywota ze względu na szykany ze strony MO i wzmacnianą przez propagandę komunistyczną niechęć społeczeństwa.

Lata 60., a zwłaszcza ich druga połowa, to również okres bezprecedensowo twórczy i przełomowy - szczególnie w obszarze muzyki rockowej. Takiej ilości nowych stylów, eksperymentów i nowatorskich brzmień nie było już potem w żadnej innej dekadzie XX wieku. Hipisi zaznaczają także tutaj swoją obecność - szczególnie w rocku psychodelicznym.

Celem artykułu jest przedstawienie jedyne małego wycinka tego, co przyniosły w muzyce lata 60., a mianowicie wybranych dokonań muzycznych z obszaru muzyki folkowej i rockowej. Ich przegląd poprzedzono krótką charakterystyką ruchu hipisowskiego w USA i Polsce. Poszukując współczesnych walorów poznawczych muzyki hipisowskiej, odwołano się za M. Rychlewskim do 4 warstw komunikatu rockowego: muzyczno-dźwiękowego, słowno-tekstowego, ikoniczno-okładkowego oraz ikoniczno-scenicznego (2011, s. 28), zarysowując także sylwetki twórców oraz tło społeczno-kulturowe epoki. W artykule wzięto pod uwagę głównie utwory z obszaru angloamerykańskiej muzyki rockowej, ale nie zabrakło też przykładów polskiej hipisowskiej twórczości muzycznej lub do takiej po latach zaliczanej. $\mathrm{Na}$ końcu artykułu podjęto próbę odniesienia wyróżnionych walorów muzycznych i pozamuzycznych do edukacji artystycznej, obywatelskiej, a także pedagogiki krytycznej czy nauczania do twórczości, które od dawna inspirują się zresztą kontrkulturowymi ideami.

\section{RUCH HIPISOWSKI NA ŚWIECIE I W POLSCE}

Tytuł artykułu zaczerpnięto oczywiście od kultowej w środowiskach hipisowskich powieści fantasy Johna Ronalda Reuela Tolkiena Hobbit, czyli tam i z powrotem (1937), której centralnym motywem, podobnie jak w późniejszym Władcy Pierścieni (1954/55),jest wędrówka. Główny bohater, Bilbo Baggins, namówiony przez krasnoludów i czarodzieja Gandalfa do opuszczenia sielskiej wsi Shire, udaje się razem z nimi w podróż, aby pomóc w odzyskaniu złota i siedziby, zrabowanych krasnoludom przez smoka Smauga. Wraca z tej wyprawy odmieniony, świadomie 
zaangażowany w kształtowanie dziejów świata, którego był wcześniej małą cząstką (Tolkien 1997).

Przygoda z ruchem hipisowskim była dla wielu młodych ludzi - zarówno w USA, jak i w Polsce, ale też w innych regionach świata - swoiście pojętą wędrówką, podczas której poznawali samych siebie oraz rzeczywistość. Niektórzy pozostali wierni kontrkulturowym ideałom do dzisiaj, czego przykładem jest duńska Christiania ${ }^{1}$.

Hipisi pojawili się w USA w latach 1964-1965. Pierwsze komuny zaczęły powstawać rok później, najpierw w Kalifornii, potem także w innych rejonach kraju (Jawłowska 1975, s. 149-153). Postawy kontestacyjne i subkulturowe zaistniały w Stanach Zjednoczonych jednak dużo wcześniej. Za prekursorów hipisów uznaje się diggersów, hipsterów oraz beatników (Filipiak 2003, s. 42-44). Były to subkultury o małym zasięgu, ale inspirujące dla późniejszych pokoleń w kwestii wzorów kulturowych, obyczajów, języka, ubioru, podejścia do muzyki etc. Diggersi, podobnie jak hipisi, preferowali wędrowny tryb życia, postulowali pacyfizm, tolerancję, swobodę obyczajów. W USA pojawili się w latach 50 . XX wieku, ale wywodzili się z Anglii, a ich korzenie sięgały jeszcze XVII wieku (Tamże, s. 42). Z kolei określenie „hipsters” zrodziło się przed II wojną światową wśród czarnych muzyków jazzowych i oznaczało ludzi, którzy „znali się na rzeczy”, „trzymali rękę na pulsie" (od słowa hep, potem hip). Z czasem zaczęto je stosować również wobec białych muzyków oraz ogólnie - wielbicieli jazzu (nazywano ich potem „białymi Murzynami"). Wtedy nabrało ono charakteru subkulturowego. Hipstersi zaznaczyli swoją obecność w latach 40. i 50. XX wieku w największych amerykańskich miastach, np. Nowy Jork, San Francisco - gdzie pojawiły się potem zresztą pierwsze grupki hipisów. Dystansowali się od stylu życia przeciętnych Amerykanów, poszukiwali nowych wartości, łącząc różne odmienne od siebie style,a także silnych wrażeń stąd narkotyki. Przypisuje im się rozpropagowanie zwyczaju palenia marihuany dla celów rozrywkowych (Wrzesień 2013, s. 74-79).

${ }^{1}$ Christiania to osiedle w dzielnicy Kopenhagi o nazwie Christianshavn. W 1971 roku do opuszczonych budynków wojskowych zaczęli nielegalnie wprowadzać się hipisi. Jeszcze tego samego roku ogłosili niepodległość. Proklamowali stworzenie wolnego społeczeństwa, niezależnego ekonomicznie, w którym zostaną zażegnanie wszelkie nierówności między ludźmi i każda jednostka - jako część wspólnoty - będzie odpowiadała za siebie. Powstały niezależne przedszkola, szkoły, poczta, kino, teatry alternatywne, sklepy. Władze Danii próbowały zlikwidować „wolne miasto”, ale w 1972 roku zawarto kompromis, który obowiązuje właściwie do dzisiaj. Mieszkańcy Christianii zobowiązali się płacić podatki. Do tej pory w Christianii można kupić marihuanę i haszysz (handel ciężkimi narkotykami jest zabroniony). Jest to „solą w oku” duńskich polityków - szczególnie konserwatystów. Osiedle leży przy tym na terenach atrakcyjnych dla deweloperów, co wydaje się prawdziwym powodem ataków ze strony rządu (Zyzda 2015; własna wizyta Autora w sierpniu 2018 roku). 
O ile hipstersi wywodzili się z niższych warstw społeczeństwa, domeną rozwijającej się od lat 40. subkultury beatników były bardziej środowiska artystyczne i akademickie. Słowo beat („pokonany”, „zrezygnowany”, „rozczarowany”) zostało zaczerpnięte ze slangu hipstersów, którymi inspirowała się beatnikowska bohema. Główni pisarze i poeci tego pokolenia stworzyli dzieła literackie, które rozpalały potem wyobraźnię „dzieci-kwiatów”. Chodzi tutaj zwłaszcza o powieść W drodze (1951) Jacka Kerouaca, która traktuje (podobnie jak Hobbit Tolkiena, choć oczywiście w bardziej „dorosły” i dosadny sposób) o podróży jako doświadczeniu poznawczo-duchowym. Inne ważne dzieła beatników toNagi lunch Williama Burroughsa (1959) oraz poemat Skowyt Allena Ginsberga (1956)². W literaturze beatowej można odnaleźć afirmację indywidualnej wolności, przekraczania granic, wędrownego trybu życia, odrzucenia wartości pokolenia dorosłych, typu: praca - rodzina - dom, narkotyków, swobody seksualnej. Obecne są również wątki podkreślające odrzucenie wartości pokolenia dorosłych, typu: praca - rodzina - dom, a także bunt przeciwko cierpieniu, wykluczeniu, mediom i polityce (Wrzesień 2013, s. 79-85). Istotną kwestią jest także to, że beatnicy rozpropagowali wśród młodych ludzi modę na słuchanie muzyki w klubach, kawiarniach (najpierw jazzu, a potem także muzyki folk), a także religie wschodnie - szczególnie buddyzm zen oraz taoizm (Sipowicz 2015, s. 20-21).

Hipisi amerykańcy, którzy pojawili się w połowie lat 60.,mieli już zatem ukształtowany grunt filozoficzny, obyczajowy, ideologiczny, religijny. Czerpali pełnymi garściami ze spuścizny diggersów, hipsterów i beatników. Amerykański ruch hipisowski tworzyła generacja młodzieży powojennego wyżu demograficznego, w większości z klasy średniej, która zbuntowała się przeciwko purytańskim normom obyczajowym i wartościom konserwatywnego pokolenia rodziców. Uważa się, że punktem kulminacyjnym ruchu hipisowskiego w USA było tzw. „lato miłości” (1967) w dzielnicy Haight-Ashbury w San Francisco, gdzie narodziła się kontrkultura hipisowska, a zmierzchem rockowy festiwal Woodstock, który odbył się w sierpniu 1969 roku na farmie koło Nowego Jorku (Castaldo 1997, s. 178-183; Goffman, Joy 2005, s. 270-271).

Przedstawiciele ruchu hipisowskiego stawiali na jakość życia, którego wartość wyznaczały: kontakt $\mathrm{z}$ naturą, rozwój duchowy (stąd fascynacje religiami i filozofią Wschodu), wolna miłość (choć nie była ona rozumiana jako niekończąca się orgia, o czym często się dzisiaj zapomina, ale intymna, szczera i autentyczna bliskość z drugą osobą), a także humanizm (jedynym celem dążeń był człowiek).

${ }^{2}$ Powieści Tolkiena i beatników to oczywiście nie jedyne książki, którymi inspirowali się hipisi. Nie można też zapomnieć o takich kultowych pozycjach jak m.in. Nowy wspaniały świat (1932) Aldousa Huxleya, Rok 1984 (1949) George'a Orwella, Wilk stepowy (1927) i Siddhartha (1922) Hermana Hessego czy też Buszujący w zbożu (1951) Jerome’a Davida Salingera. 
Hipisi preferowali życie poza rutyną od 9 do 5, według własnego rytmu i tempa, odcinali się od konsumpcji i wyścigu szczurów. Odrzucali karierę i sukces jako wartości, a także rywalizację, współzawodnictwo na rzecz współpracy, kooperacji. Preferowali życie we wspólnocie (tzw. komunie). Głosili także pacyfizm, nonkonformizm, egalitaryzm w podejściu do sztuki czy edukacji, a potem również ekologizm (Jankowski 1972; Jawłowska 1975, s. 148-166).

Zewnętrznie hipisi wyróżniali się ekscentryczną kolorową modą. Nosili długie włosy, koraliki, kolorowe koszule (w barwach ziemi), spodnie dzwony (Pęczak 2013, s. 67).Strój i zachowania nie zawsze łączyły się jednak z wyznawaniem idei i ruchu hipisowskiego. Zarówno na Zachodzie, jak i w Polsce istnieli tzw. „weekendowi” czy „wakacyjni” hipisi, których bardziej interesowały zewnętrzne wyróżniki ruchu i chęć zabawy niż jego filozofia (Jankowski 1972, s. 72-73; Pęczak 2013, s. 64).

Jednym z weekendowych hipisów, aczkolwiek świadomym niektórych kontrkulturowych idei, był - jako nastolatek - Peter McLaren (obok Paula Freirego i Henry'ego Girouxa główny twórca pedagogiki krytycznej). W 1968 roku odwiedził San Francisco, aby zaprotestować przeciwko wojnie w Wietnamie i tam poznał Timothy'ego Leary'ego i Allena Ginsberga - wtedy głównych „kapłanów" ruchu hipisowskiego, co bez wątpienia miało wpływ na jego twórczość pedagogiczną(McLaren 2015, s. 315-432).

Psychoaktywne używki (zwłaszcza marihuana oraz LSD) były kluczowym elementem zachodniej kontrkultury hipisowskiej lat 60. (Tracz 2014, s. 89). Odcisnęły piętno nie tylko na muzyce, ale także modzie, sztukach wizualnych, filmie, teatrze, literaturze czy poezji (Lundborg 2012). LSD, czyli Lysergic acid diethylamide (zwyczajowo zwany „kwasem”), to substancja wyizolowana w 1938 roku ze sporyszu atakującego żyto przez szwajcarskiego chemika Alberta Hofmanna, który 5 lat potem (1943) przypadkowo odkrył jej psychoaktywne właściwości i przeprowadził na sobie pierwsze eksperymenty (Hofmann 2016, s. 15-32). LSD okazało się użyteczne w obszarze psychiatrii (w leczeniu psychoz), zaczęło się nim interesować także wojsko oraz służby wywiadowcze w kontekście białej broni czy kontroli umysłu (Balawender 2012, s. 119-122). Opowieści o cudownych właściwościach nowego leku (poszerzającego świadomość, wzmagającego kreatywność i dającego mistyczne przeżycia) przyciągnęły uwagę artystów, a potem hipisów, którzy uczynili z niego główny element swojej filozofii czy nawet religii (do października 1966 roku LSD było w USA całkowicie legalne). (Sipowicz 2015, s. 40). Istotną rolę odegrał tutaj Timothy Leary- amerykański psycholog z Harvardu - który badał działanie tego narkotyku, a po wydaleniu z uczelni założył religijną wspólnotę, krzewiącą kontrkulturowe idee (Hofmann 2016, s. 90). Zażywanie halucynogenów było jednym z głównych elementów tej nowej religii i miało prowadzić do poznania samego siebie i świata (Jawłowska 1975, s. 270). Hipisi nazywali zresztą 
trip po LSD „zastępczym oświeceniem” (instant satori) (Krzan 2008, s. 101-133). W przypadku rocka, LSD było łącznikiem między muzykami i fanami, gdyż narkotyk miał prowadzić do pełniejszego zrozumienia muzyki (Storey 2003, s. 99).

W Polsce ruch hipisowski miał mały zasięg i działał niejako w podziemiu. Hipisi pojawili się w drugiej połowie lat 60., początkowo głównie w dużych miastach, takich jak Kraków, Warszawa, Łódź, Wrocław, Gdańsk (Sipowicz 2015, s. 99). Liderzy wywodzili się zwykle ze środowisk inteligenckich, zaś członkowie w większości z ubogich rodzin robotniczych (Tracz 2014, s. 160-163). Podobnie jak zachodni koledzy - o których polscy hipisi czerpali szczątkowe informacje od zagranicznych turystów lub osób wyjeżdżających do krajów zachodnich albo też nielicznych (w większości propagandowych) artykułów z krajowej prasy (Sipowicz 2015, s. 112-117) - spotykali się w klubach, kawiarniach lub na zlotach, często rozpędzanych przez komunistyczną Milicję Obywatelską (MO). Najsłynniejsze zloty odbyły się w 1968 roku w Mielnie i Dusznikach-Zdroju oraz w 1969 roku w Kazimierzu Dolnym. W kolejnych latach stałym miejscem spotkań stała się Częstochowa oraz pobliski Olsztyn, gdzie hipisi mogli się skryć między pielgrzymami idącymi w sierpniu na Jasną Górę (Tracz 2014, s. 200-230).

Długowłosi i kolorowo ubrani osobnicy (nie tylko hipisi, ale także ich naśladowcy, głównie studenci i artyści) byli ścigani i prześladowani przez MO oraz SB (Służbę Bezpieczeństwa). Zdarzały się też akcje przymusowego obcinania włosów (Tracz 2014, s. 180-185). Hipisi nie pasowali do PRL-owskiej wizji państwa, w myśl której taki styl życia i sposób ubierania się był wyłomem w socjalistycznej szarości i hołdowaniem wrogim zachodnim siłom (Sipowicz 2015, s. 118-126).

Polscy hipisi nie protestowali rzecz jasna przeciwko kapitalizmowi czy konsumpcji jak na Zachodzie, gdyż takie rzeczy w ówczesnej Polsce nie istniały, ale przeciwko komunistycznej opresji, braku swobód demokratycznych oraz socjalistycznemu kultowi pracy (Sipowicz 2015, s. 114-117). Podzielali jednak zachodnie idee pacyfistyczne, czego konsekwencją było unikanie służy wojskowej (Tracz, s. 168-170). Na polskim gruncie nie przyjęły się także idee wolnej miłości czy odrzucenia wartości rodzinnych, a także konwersje religijne (buddyzm, taozim). Wielu hipisów było wierzących i nigdy nie porzuciło wartości katolickich. Niektórzy z nich za „duchowego opiekuna” uważali ks. Andrzeja Szpaka, organizatora pielgrzymek do Częstochowy (Gogola 2012, s. 44-45). Komuny hipisowskie również należały do rzadkości. Najsłynniejsze istniały w Ożarowie oraz Podkowie Leśnej koło Warszawy czy w Bieszczadach (Tracz 2014, s. 230-232). Ulubionym zajęciem hipisów, podobnie jak na Zachodzie, były (zgodnie z beatnikowskim „życiem w drodze”) wędrówki, do czego często używali autostopu (Tarzan-Michalewski 1992, s. 16, 21).

Polscy hipisi nie mieli dostępu do „kultowych” narkotyków, takich jak marihuana i LSD. Czasem otrzymywali je w prezencie od turystów z Zachodu (Tracz 
2014, s. 307-315). Pojawiły się zatem polskie substytuty. Jednym z nich był rozpuszczalnik będący składnikiem wybielacza plam o nazwie Tri, zwanym „klejem”, który wywoływał silne halucynacje (Sipowicz 2015, s. 329). Zażywano także leki: parkopan (lek na chorobę Parkinsona) i astmosan (zioła do inhalacji dla astmatyków), które zawierały atropinę - substancję zawartą naturalnie w np. wilczej jagodzie (Schultes 1976, s. 46). Wywoływały one kilkugodzinne stany odurzenia, którym towarzyszyły halucynacje. Popularnym substytutem była też fenmetrazyna (zawierająca pochodne amfetaminy), zwana potocznie „fermą". Zwiększona dawka likwidowała uczucie zmęczenia i wzmagała zdolność koncentracji (Tracz 2014, s. 301-304). W latach 70. pojawiła się polska odmiana marihuany (tzw. samosiejka), a w połowie dekady „kompot”, pozyskiwany z maku, chociaż już wcześniej stosowano morfinę. Narkotyki opiumowe to najczarniejsza karta w historii polskiego ruchu hipisowskiego. Miały silne działanie uzależniające i przyniosły ogromną ilość ofiar (Tarzan-Michalewski 1992).

Kres ruchowi hipisowskiemu, przynajmniej w pierwotnej formie, położyła zorganizowana przez MO i SB pod koniec 1971 roku akcja „Porządek”, której częścią były operacje „Mak”, skierowane przeciwko hipisom. Członkowie, z obawy przed aresztowaniami, unikali spotkań, co uszczupliło ruch (Tracz 2014, s. 455-503). Hipizm odrodził się w Polsce w latach 80. Przedstawiciele nowej generacji hipisów stali się bywalcami festiwali jarocińskich, razem z punkowcami, metalowcami i fanami reggae (Idzikowska-Czubaj 2011, s. 305-307).

Ruch hipisowski, mimo programowej antysystemowości i apolityczności (potem zresztą przełamanej, o czym będzie dalej mowa), zrodził wiele trwałych wartości, które na zawsze odmieniły rzeczywistość społeczno-kulturową. Najtrwalszą z nich wydaje się muzyka rockowa, której słucha się do dzisiaj, bez względu na stosunek do hipisowskich wartości.

\section{OBLICZA MUZYKI HIPISOWSKIEJ - WYBRANE PRZYKŁADY}

Muzyka, której słuchali hipisi, wpisywała się w szerokie koncepcje sztuki. Za ich cechę ogólną można uznać egalitaryzm - twórczość miała być dostępna dla każdego, bez względu na formalne wykształcenie i zdolności (Jawłowska 1975, s. 209-210). Muzyka hipisowska miała różne oblicza, wśród których w dzisiejszej perspektywie najważniejsze wydają się dwa: protest-songi (przywłaszczone przez hipisów od folksingerów i lewicującej młodzieży akademickiej) oraz rock psychodeliczny (już oryginalny „produkt” hipisowski, aczkolwiek tworzony przez różnych artystów, nie zawsze związanych $\mathrm{z}$ ruchem). $Z$ tego drugiego rozwinęła się potem cała gama gatunków i stylów - równie ważnych dla hipisów -takich jak: rock progresywny, jazz-rock, hard rock. 
Dla pierwszych amerykańskich hipisów ogromne znaczenie miała muzyka folk. Ludowe ballady i bluesy białej ludności znalazły najpełniejszy wyraz w twórczości Woody'ego Guthriego i Pete'a Seegera jeszcze w latach 40. XX wieku. Zafascynowani ideami nowej lewicy, w swoich prostest-songach proklamowali oni wizję egalitarnej i niemal komunistycznej Ameryki, w której idee wspólnotowości nie stoją w sprzeczności z demokracją (Castaldo 1997, s. 43-45).

Tym, co wniósł folk do muzyki hipisowskiej i potem ogólnie - rocka, była koncepcja autentyczności w muzyce. W pieśniach folkowych ważny był wokal oraz tekst, wykonywany przy skąpym akompaniamencie gitary czy pianina. Najbardziej liczyła się szczerość przekazu, która zawierała się w zasadzie w głosie, linii wokalnej pozbawionej ozdobników. Ważny był też bezpośredni kontakt z publicznością, zacierający granice między wykonawcami i odbiorcami, który tworzył świadomość wspólnoty. Było to możliwe szczególnie w klubach, zanim pojawiły się elektryczne instrumenty (Frith 1982, s. 28-29). Nagłośnienie odsunęło nieco publiczność od sceny, ale więź nie zanikła, co pokazywały późniejsze koncerty i festiwale.

Wraz ze zmierzchem politycznego radykalizmu w USA (koniec lat 40.), lewicowe pieśni folkowe straciły znaczenie. Ich wspólnotowo-klubowy sposób wykonywania przetrwał jednak w kampusach uniwersyteckich i stał się częścią kultury studenckiej w USA. Folkowy protest-song odrodził się na początku lat 60., w czasach politycznego ożywienia, studenckich rewolt, działalności ruchu na rzecz praw obywatelskich. Peter Seeger, którego lewicujące pieśni blokowała w latach 50. cenzura, stał się wówczas symbolem niekomercyjnej, intelektualnej ekspresji stojącej w opozycji do banalnych produktów muzyki pop, a także niezależności od przemysłu muzycznego (Frith 1982, s. 29-30; Castaldo 1997, s. 44). Ideał ten ożyje potem wśród hipisowskich grup psychodelicznych, które będą unikały podpisywania kontraktów, aby nie wejść w kapitalistyczne mechanizmy rynku i ocalić muzyczną autentyczność (np. GratefulDead, Jefferson Airplane). Intelektualne teksty (Dylana, Beatlesów czy The Who) staną się też tym, co zwyczajowo będzie odróżniało rozrywkowy rock and roll od intelektualnego i zaangażowanego społecznie rocka połowy lat 60 .

Pierwsza połowa lat 60. to czasy prostest-songów Boba Dylana i Joan Baez czy Phila Ochsa. Działały wówczas w USA młodzieżowe organizacje i ruchy, takie jak SDS, czyli Students for a Democratic Society - organizacja wywodząca się ruchu nowej lewicy i upominająca się o prawa obywatelskie, wolność słowa, propagująca pacyfizm oraz Partia Czarnych Panter, postulująca równość rasową i odrębność Afroamerykanów. Walczyły one nie tylko o zmianę społeczną, ale także przeobrażenia w kulturze (Jawłowska 1975, s. 25-27).

${ }^{3}$ Jeśli chodzi o Europę, można tu doliczyć działających jeszcze w latach 50. sytuacjonistów (ruch społeczno-artystyczny, zafascynowany surrealizmem, dadaizmem, gdzie sztuka i polityka 
Idee powyższych formacji politycznych podjął w swoich utworach Bob Dylan, uznawany za symbol tamtego pokolenia (Garztecki 1978, s. 207). Za sprawą swoich poetyckich tekstów, śpiewanych surowym głosem, a także niespotykanego wcześniej w tej muzyce osobistego wglądu w rzeczywistość społeczną, Dylan stworzył nowy model autentyczności w folku (Frith 1982, s. 30). W balladzie Blowing in the Wind (1963) dostrzegano główne pragnienia ówczesnej generacji młodzieży: wołanie o pokój i kres rasizmu (Pichaske 1989, s. 58). Idee rewolucji młodzieżowej zawarte są także na zaangażowanym albumie The Times TheyAre A-Changin' (1964). Jeszcze w 1964 roku Dylan przestał jednak pisać protest-songi, a rok później wystąpił na folkowym festiwalu w Newport z gitarą elektryczną, czym zraził do siebie starych fanów. Częste zmiany muzycznego stylu stały się odtąd jego znakiem firmowym (Castaldo 1997, s. 79-81). Chociaż czuł klimat hipisowskiej epoki, o czym świadczy eskapistyczny w wymowie utwór Mr. Tambourine Man(1965)czy psychodeliczne brzmienia na albumie Blonde On Blonde(1966), jednocześnie ją przekraczał, dystansował się od ruchu hipisowskiego. W szczytowym okresie popularności psychodelicznego rocka zaczął śpiewać country (np. płyta John Wesley Harding z $1967 \mathrm{roku}$ ). Nie wystąpił również na festiwalu Woodstock, mimo że mieszkał wówczas dokładnie w tym mieście ${ }^{4}$.

Około roku $1965 \mathrm{z}$ beztroskiego rocka and rolla lat 50., za sprawą Boba Dylana, The Who, Rolling Stonesów i Beatlesów, wyłonił się gatunek muzyczny pretendujący do miana sztuki, czyli rock (Kurowski 1992, s. 112-120). Mniej więcej w tym samym czasie moda na poszerzanie świadomości za pomocą środków psychoaktywnych (LSD, marihuana), podsycana dodatkowo przez Timothy'ego Leary'ego i innych „kapłanów” ruchu hipisowskiego (m.in. Allena Ginsberga, Kena Keseya), doprowadziła do zaistnienia nowego stylu w obrębie rocka, który nazwano rockiem psychodelicznym lub acid rockiem (Echard 2017, s. 29-64; Turner 1997, s. 50-63).

Terminu „psychedelic” w kontekście muzyki pierwsza użyła w 1964 roku w tekście jednego $\mathrm{z}$ utworów nowojorska folkowa grupa The Holy ModalRounders, a następnie zespół The 13th Floor Elevators z Teksasu na płycie The Psychedelic Sounds of the 13th Floor Elevators (1966) (Szlendak 2012, s. 105; Dorobek 2016, s. 129). Rock psychodeliczny jest blisko spokrewniony z acid rockiem, który wyłonił się mniej więcej w tym samym czasie na zachodnim wybrzeżu USA i dotyczył w szczególności muzyki takich grup, jak Iron Butterfly, VanillaFudge czy (wczesny) The Byrds. Używały one podczas występów wielobarwnych efektów wizualnych

miały być jednym) oraz ruch holenderskich Provosów (uważanych za prekursorów europejskich hipisów), przekształcony potem w Partię Krasnoludków (Jawłowska 1975, s. 114-134).

${ }^{4}$ Impreza odbyła się tak naprawdę na farmie w miasteczku Bethel, niedaleko Woodstock (Jarniewicz 2016, s. 250). 
(m.in. plamy świetlne, wirujące strugi światła, filmy), a także efektów modyfikujących brzmienie instrumentów lub głosu (Michalski 1990, s. 204, 216-217).

Muzyka zespołów psychodelicznych miała odzwierciedlać za pomocą środków muzycznych i tekstowych (a podczas koncertów dodatkowo - wizualnych) takie przeżycia lub też intensyfikować „odlot” po zażyciu narkotyków (Szlendak 2012, s. 105-109). Potem nałożyły się jeszcze na to filozofie i religie Wschodu, mistycyzm, medytacja transcendentalna (Macan 2001, s. 6; Turner 1997, s. 64-83). Elementy kultur orientalnych pierwsi wprowadzili do muzyki rockowej Beatlesi, używając sitaru w utworze Norwegian Wood z płyty Rubber Soul (1965). Gitarzysta tej grupy - George Harrison - rozwinął ten patent i nauczył się grać na sitarze u wirtuoza tego instrumentu Ravi Shankara w Bombaju, co znalazło najpełniejszy wyraz w utworze Within You Without You z płyty Sgt. Pepper's Lonely Hearts Club Band (1967), nagranym z udziałem hinduskich muzyków (Jarniewicz 2016, s. 134).

Rock psychodeliczny był pewną konwencją estetyczną, obejmującą różnych stylowo wykonawców (Dorobek 2016, s. 121-123). Od początku styl ten występował w dwóch wariantach: amerykańskim i brytyjskim. Można powiedzieć, że w pierwszym przypadku obejmował całe Stany Zjednoczone, ale centrum stanowiło San Francisco, jako mekka hipisów i kontrkultury. Działały tam zespoły folkowo-bluesowe i countrowe, takie jak Quicksilver Messenger Service, Country Joe \& The Fish, Iron Butterfly oraz liczne grupy amatorskie. Unikały one - przynajmniej z początku - podpisywania kontraktów, i chciały funkcjonować (zgodnie z założeniami kontrkultury) poza kapitalistycznym rynkiem. Warto dodać, że działalność w zespołach hipisowskich była stylem życia, czego przykładem są kalifornijskie zespoły-komuny, takie jak np. The Grateful Dead, Big Brother And The Holding Company czy Jefferson Airplane.

Istotnymi centrami rocka psychodelicznego były także Nowy Jork (VanillaFudge) oraz Los Angeles i okolice (The Byrds, Mamas and the Papas, The Doors, Love, Mothers of Invention). W dwóch ostatnich regionach zespoły nawiązywały jedynie do tego stylu w pojedynczych utworach, na okładkach płyt i czasem tylko debiutanckich, co stanowiło marketingowy ukłon w stronę powszechnej mody (Castaldo 1997, s. 124-177; Dorobek 2016, s. 127-128).

Brytyjski wariant rocka psychodelicznego można podzielić na trzy nurty: zakorzeniony w elektrycznym rhythm'n'bluesie, który dał potem początek heavy metalowi (The Rolling Stones, The Who, The Yardbirds, The Cream, The Jimi Hendrix Experience), jazzrockowy (Traffic, Colosseum, Soft Machine) oraz protoprogresywny (Moody Blues, Procol Harum, Pink Floyd, The Nice), który wywodził się od eksperymentujących Beatlesów i przyczynił się do powstania rocka progresywnego lat 70. (Macan 2001, s. 10-16). Uważa się, że gitarowe psychodeliczne brzmienie w Wielkiej Brytanii zaczęli The Yardbirds w utworach StillI'm 
Sad czy Heart Full Of Soul (1965) oraz The Kinks na singlu See My Friends(1965), a Beatlesi to potem rozwinęli. Szczególnie chodzi tutaj o utwory typu: Rain (1966), Tomorrow Never Knows z płyty Revolver (1966), Strawberry Fields Forever (1967) czy kultowy album Sgt. Pepper's Lonely Hearts Club Band (1967), będący szczytowym osiągnięciem tego stylu (Echard 2017, s. 29-64, 90-95, 160-190). To samo można powiedzieć o płycie Electric Ladyland (1968) Hendrixa, która wyznaczyła nowe kierunki studyjnych eksperymentów (Szlendak 2012, s. 108).

W Polsce rock hipisowski działał niejako w podziemiu. Określenie „rock and roll" nie było w PRL-u mile widziane przez antyamerykańskie władze komunistyczne, dlatego zastąpiono je terminem „big beat” (Gnoiński, Skaradziński 2001, s. 76-77). Partia kontrolowała wszystkie przedsięwzięcia artystyczne i narzucała własną politykę kulturalną. Wskazane było wykonywanie songów o tematyce patriotycznej, socjalistycznej, najlepiej w konwencji muzyki ludowej (Brzozowicz 2016, s. 58-63). Niektóre zespoły wyspecjalizowały się w łączeniu big beatu z folklorem (Niebiesko-Czarni, No To Co, Skaldowie). Polskie grupy borykały się poza tym z cenzurą (w kwestii tekstów) oraz brakiem dobrego sprzętu, instrumentów, nagłośnienia. Przystawki gitarowe tworzono z początku samodzielnie, podobnie było w przypadku oświetlenia scenicznego (Gaszyński 2012, s. 432; Michalski 2014, s. 598, 624-625).

Nawiązania do muzyki zachodniej musiały być dyskretne, zakamuflowane. Wtedy były szanse zaistnienia w szerszym obiegu, na estradzie, $w$ telewizji, radiu. Odważniejsze próby ekspresji, mimo poparcia publiczności, były tłamszone i nawet jeśli udało się komuś wyjść z cienia, utrudniano mu skutecznie życie. Przykładem jest Czesław Niemen, twórca pierwszego polskiego protest-songu Dziwny jest ten świat (1967), który cieszył się wśród polskiej młodzieży sławą równą utworom Dylana (jak i zresztą sam jego kompozytor). Dla ówczesnych władz Niemen był jednak niebezpiecznym indywidualistą i ekscentrykiem (Jaśkiewicz, Górka 2014, s. 106-108). Jak większość muzyków bigbeatowych, odcinał się on od polskiego ruchu hipisowskiego, chcąc zapewne uniknąć problemów z milicją, aczkolwiek okładki płyt takich jak Sukces (1968) oraz Czy mnie jeszcze pamiętasz (1969) nawiązywały do estetyki flower-power. Takich odniesień było w ówczesnym big beacie więcej - w muzyce, tekstach, wizerunku scenicznym czy oprawie świetlnej koncertów (Skaldowie, Czerwone-Gitary, Dżamble, Anawa, Breakout).

Najważniejsze dla polskich hipisów zespoły koncertowały głównie w klubach. Można ich było także posłuchać na trwającym krótko (3 edycje, w latach: 1969, 1972,

${ }^{5}$ Nawet w latach 70. idee filozofii i estetyki hipisowskiej pojawiały się jeszcze dość często np. rock-opera Naga zespołu Niebiesko-Czarni (1971), płyta Mrowisko grupy Klan (1971), do której stworzono spektakl wystawiony pierwszy raz rok wcześniej w Opolu, czy utwór Odlot z pierwszej płyty SBB (1974). 
1973) Festiwalu Awangardy Beatowej w Kaliszu (Michalski 2014, s. 763-773). Na przełomie lat 60. i 70. XX wieku we Wrocławiu działał zespół Romuald \& Roman, stosujący psychodeliczne oświetlenie sceniczne oraz długie improwizacje gitarowe w stylu Grateful Dead. W tym samym czasie w Krakowie acid-rockowe spektakle wystawiał Zdrój Jana, ale bardziej w klimacie studenckich kabaretów (Michalski 2014, s. 596-601; Sipowicz 2015, s. 327). Można tu jeszcze doliczyć grupę Breakout pochodząca z Rzeszowa (szczególnie albumy Na drugim brzegu tęczy z 1969 roku czy 70a z 1970), Grupę 74 Biednych z Ustki, przedstawiającą w barwnych strojach happeningi muzyczne o zabarwieniu rockowo-jazzowym, a także ożarowską Grupę w Składzie:. Ostania z nich nie miała wiele wspólnego z rockiem, wykonywała muzykę eksperymentalną, awangardową, w całości improwizowaną (Sipowicz 2015, s. 376-379). Poza Breakoutem wszystkie powyższe zespoły były undergroundowe i zostawiły po sobie nieliczne nagrania. Do legendy przeszły natomiast ich koncerty, na których używały migoczących reflektorów, projektorów, dymów, pokazów filmów (zwłaszcza Romuald \& Roman i Zdrój Jana, przez chwilę też Breakout). Kluczową rolę w przeszczepieniu estetyki psychodelicznej na grunt polski odegrał Franciszek Walicki, animator polskiego big beatu i założyciel czy też opiekun artystyczny najważniejszych zespołów z tego okresu(Michalski 2014, s. 793-817). Pod pseudonimem Jacek Grań stworzył surrealistyczne teksty utworów Na drugim brzegu tęczy oraz Dziwny weekend (dla zespołu Breakout) oraz Odlot (dla grupy SBB) - dyskretnie nawiązujące do podróży narkotycznych.

Wnikając głębiej w amerykańską twórczość psychodeliczną i próby jej naśladowania na gruncie polskim, można przyjrzeć się jej przez pryzmat warstw kodu muzycznego, wyróżnionych przez M. Rychlewskiego (2011, s. 28). I tak, w warstwie muzycznej w rocku psychodelicznym położono nacisk na eksperymenty, sonorystykę i kolorystykę: występują efekty brzmieniowe (przystawki gitarowe, organowe), czasem nawet kontrasty dynamiczne - jak w muzyce artystycznej, a w warstwie wokalnej pojawiają się deklamacje, recytacje. Utwory cechuje różnorodna faktura, mają rozbudowane i otwarte formy, przez co przekraczają one czas standardowych singli (3-4 minuty). Jak pisze A. Jawłowska, twórczość miała być „ekspresją spontaniczną, wymykającą się narzuconym z zewnątrz estetycznym kanonom” (Jawłowska 1975, s. 208), dlatego w muzyce ceniono improwizację. W utworach występują długie sola gitarowe, jak w improwizacjach jazzowych (np. Hendrix, GratefulDead, Yardbirds, Soft Machine, Pink Floyd, Romuald \& Roman).

W warstwie słowno-tekstowej dominują surrealistyczne, abstrakcyjne teksty, naśladujące „strumień świadomości” Jamesa Joyce’a (np. I Am the Walrus The Beatles). Słowa utworów nie mówiły o narkotykach wprost z obawy przed oskarżeniami o demoralizację młodzieży, propagowanie zabronionych przez prawo środków etc. Zarówno w USA, jak i w Polsce działała cenzura. W tekstach wystę- 
powały więc dwie warstwy znaczeniowe. Pierwsza (oficjalna, zewnętrzna) mogła przypominać surrealistyczną grę słów, zaś druga (narkotyczna) była oczywiście zrozumiała tylko dla wtajemniczonych (Stuessy, Lipscomb 2002, s. 122-123; Storey 2003, s. 99). Sami muzycy często też zaprzeczali jakoby ich utwory miały coś wspólnego z narkotykami, co oczywiście podsycało ciekawość fanów i opinii publicznej, nadawało wymiar obcowania z jakimś tabu (Turner 1997, s. 57-60). Dla przykładu, zespół The Byrds twierdził, że piosenka Eight Miles High (1966), uznawana za jeden z pierwszych utworów psychodelicznych, traktuje o podróży samolotem (Stuessy, Lipscomb 2002, s. 193). Podobnie było z Lucy in the Sky with Diamonds (1967) The Beatles z płyty Sgt. Pepper's... autorstwa Johna Lennona, gdzie pierwsze litery słów użytych w tytule tworzą skrót „LSD”. Muzyk twierdził, że piosenka powstała pod wpływem rysunku jego syna o takiej właśnie tematyce (Tamże, s. 126). Czasem inspiracji oraz podwójnych znaczeń dostarczała literatura. Tak było z książkami Louisa Carrolla, powstałymi przypuszczalnie pod wpływem opium (Connell 1997). Postacie i motywy z Przygód Alicji w Krainie Czarów(1865) pojawiają się w utworze White Rabbit Jefferson Airplane (1967). Z kolei I Am the Walrus The Beatles (1967) odwołuje się do Alicji po drugiej stronie lustra (1871). W Polsce sztandarowym przykładem takich narkotykowych aluzji pozostaje Towarowy rusza do Indii zespołu Romulad \& Roman, w którym pierwsze litery użytych wyrazów (podobnie jak w Lucy in the Sky with Diamonds) układają się w nazwę „TRI”. Grupa nagrała ten utwór po kryjomu w studenckim studiu w 1972 roku. Na koncertach był wykonywany ze zmienionym tekstem (Michalski 2014, s. 650-651). Ujrzał światło dzienne dopiero na składance wydanej w latach 90.

Jeśli chodzi o kwestie polityki, obywatelstwa, krąży opinia, że pierwsi hipisi (w przeciwieństwie do lewicujących studentów epoki Dylanowskich protest-songów) deklarowali apolityczność (Tracz 2014, s. 79-83). Odmawiali uczestnictwa w systemie, gdzie są łamane zasady demokracji, a młodzi ludzi są wysyłani na śmierć w bezsensownych wojnach wymyślonych przez polityków (Wietnam). Jednakże, A. Jawłowska przywołuje dane, że ok.3/4 członków organizacji SDS sympatyzowało z ruchem hipisowskim (1975, s. 157), zatem byli uświadomieni obywatelsko, politycznie. Po symbolicznym „pogrzebie hipisa” (w październiku 1967), hipisi przekształcają się w ruch Yippies (Youth International Party), którego liderami zostali Abbie Hoffman i Jerry Rubin. Był to już ruch świadomie zaangażowany politycznie. Jego członkowie buntowali się przeciwko nalotom policji na Hight-Ashbury w San Francisco, aresztowaniom, próbom likwidacji komun, a także traktowaniu ich jako atrakcji turystycznej, dlatego miał miejsce ów symboliczny „pogrzeb”, oznaczający w zasadzie koniec ruchu w jego pierwotnej formie (Tamże, s. 153-154). Yippies zapowiedzieli walkę przeciw opresyjnemu, zakłamanemu i bezdusznemu, ich zdaniem, systemowi społeczno-politycznemu w USA, którego 
tendencje imperialne prowadzą do wojen, wyzysku i rasizmu, gdzie rządzi pieniądz i pracuje się tylko po to, aby przetrwać. Upomnieli się również o prawa kobiet, dzieci i zwierząt. Zaczęli zakładać własne przedszkola i szkoły. Interesowały ich też problemy służby zdrowia, rzemiosła, sztuki. Mimo że pierwsza faza działalności YIP zakończyła się krwawymi zamieszkami i aresztowaniami oraz zejściem ruchu do „podziemia” (Tamże, s. 154-156), idee i wzorce przetrwały. Można je odnaleźć chociażby w duńskiej Christianii.

Rewolucyjną atmosferę tamtych lat obrazuje utwór Volunteers Jefferson Airplane (1969). Oddaje on jednak bardziej emocje, nie zawiera wyraźnych deklaracji politycznych, podobnie jak spektakularne i pacyfistyczne w wymowie wykonanie przez Hendrixa hymnu USA, pełnego efektów gitarowych imitujących wybuchy bomb (podczas festiwalu w Woodstock). Inaczej jest w Revolution The Beatles (1968), gdzie Lennon z charakterystycznym dla siebie sarkazmem podważa działalność nowej lewicy, działania prowadzące do zamieszek, niszczenia mienia czy zbiórki pieniędzy na wsparcie różnych działań i organizacji - co do dzisiaj jest problemem. Utwór ma zatem wymowę ponadczasową. Lennon krytykuje radykalne działania, hasła przepełnione nienawiścią, terroryzm. Zarzuca nowej lewicy brak pomysłu na przyszłość. Twierdzi, że najpierw potrzebna jest zmiana świadomości. Jak w wielu dwuznacznych tekstach Lennona nie wiadomo jeszcze czy chodzi tu o doświadczenie psychodeliczne, niosące poczucie miłości totalnej, czy może już świadome zaangażowanie obywatelskie.

W warstwie ikonograficzno-okładkowej na kopertach płyt występują kolorowe, quasi-secesyjne wzory i czcionki. Styl ten zapoczątkował plakat nowojorskiego grafika Wesa Wilsona z charakterystyczną pstrokatą czcionką (Michalski 2014, s. 762). Rozwija się koncepcja albumu rockowego (Rychlewski 2011, s. 42) czy nawet koncept-albumu (Sgt. Pepper's Lonely Hearts Club Band).

W warstwie scenicznej kontemplacji muzyki towarzyszyły, jak już wspomniano, wielobarwne efekty wizualne, a także kolorowe stroje artystów, dające złudzenie uczestnictwa w spektaklu odbywającym się poza codzienną rzeczywistością. Nie tylko w środowiskach hipisowskich chciano wówczas odejść od wizji sztuki jako czegoś odrębnego od natury, dlatego z jednej strony ceniona była muzyka o charakterze rytmicznym, aktywizująca ciało i emocje (Jawłowska 1975, s. 208-210). Być może stąd brała się fascynacja bluesem, soulem, muzyką Czarnych Amerykanów (silniejsza wówczas w muzyce brytyjskiej). Z drugiej strony był to rock psychodeliczny - kontemplacyjny, odbierany wyostrzonymi przez środki psychoaktywne zmysłami. Muzyka miała przy tym być „ekspresją kolektywną (...) źródłem zbiorowych reakcji i przeżyć” (Tamże, s. 209), gdzie rozmywa się podział między odbiorcą a twórcą. Koncert artysty przed publicznością był więc kolejnym przejawem autentyczności - w zasadzie jeszcze według wzorców ustalonych przez 
Dylana. Największe znaczenie miała muzyka wykonywana na żywo, czylikoncerty klubowe, a potem młodzieżowe festiwale muzyczne i największy z nich Woodstock 1969, uważany za wielki finał epoki flower-power.

\section{PODSUMOWANIE}

Jakie zatem walory poznawcze płyną dzisiaj z muzyki hipisowskiej? Czy ma ona potencjał edukacyjny?

Na pewno nie da się opowiadać o muzyce lat 60. pomijając samych hipisów, a także ich filozofię, wartości, problemy, dążenia. Wgląd w hipisowską muzykę oraz towarzyszące jej koncepcje sztuki i życia ujawnia m.in. potrzeby, pragnienia, niepokoje i marzenia młodzieży (zarówno wtedy, jak i dzisiaj nie do końca rozpoznane i rozumiane), co wydaje się kluczowym i wciąż aktualnym problemem całej pedagogiki.

Hipisi amerykańscy dopominali się realizacji założeń humanizmu - z naciskiem na słowo „realizacja”, aby to, co się głosi (i w sumie to, czego ich nauczono w szkołach, na uczelniach), miało zgodność z tym, co się robi. Najważniejsze miejsce w ich systemie wartości zajęło po prostu życie, świadome przeżywanie egzystencji we wspólnotowym związku z innymi i naturą. Apelowali o odnowę stosunków międzyludzkich, opartych na zaufaniu, akceptacji, otwartości (Jawłowska, s. 149-151). Hipisi pragnęli,» «dotknąć» rzeczywistościsamej, doznawać, przeżywać intensywnie, czuć siebie naprawdę, nie w sposób narzucony przez wymagania szkoły czy wzorce propagowane przez środki masowego przekazu" (Tamże, s. 150), czyli de facto - wyjść poza system, który jawił się jako zepsuty i opresyjny. Stąd tendencje eskapistyczne: od młodzieńczych ucieczek z domu i porzucania szkoły, przez wędrówki i podróże (także na Wschód), po koncepcje „rozszerzania świadomości” za pomocą medytacji czy narkotyków halucynogennych, a także intensyfikowania za ich pomocą odbieranej muzyki.

Hipisi przypomnieli światu, że stosowanie środków psychoaktywnych towarzyszyło ludzkości od zarania dziejów i używano ich w celach religijnych, leczniczych oraz rekreacyjnych (Eliade 1994; Grof 2010). Przyczynili się jednak również do zablokowania użytecznych dla psychiatrii badań nad LSD, które w wyniku młodzieżowej mody przekształciło się w narkotyk nadużywany w celach rekreacyjnych (Hofmann 2016, s. 65-75). Historia polskiego ruchu hipisowskiego znakomicie przedstawiona przez jego uczestnika i potem lidera - Wojciecha Tarzana-Michalewskiego w książce Mistycy i narkomani przestrzega także przed nadużywaniem narkotyków(nie tylko ciężkich) i przypomina o ofiarach popularnego w Polsce w latach 70. i 80. XX wieku „kompotu”. Dzisiaj coraz więcej państw 
depenalizuje marihuanę - nie tylko w celach leczniczych (np. w czerwcu 2018 Kanada), co również wydaje się jakąś kontynuacją/powrotem do hipisowskich trendów kulturowych.

Fascynacje kulturą Wschodu czy innymi religiami (taoizmem, buddyzmem zen, jogą czy wczesnym chrześcijaństwem) wyprzedzają wprawdzie hipisów, ale ranga, którą w XX wieku nadali oni tym doświadczeniom sprawia, że można ich uznać za prekursorów New Age. Podobnie jest ze źródłami współczesnego ekologizmu, który wyrósł na ideach kontrkulturowych. Także rewolucja seksualna, której hipisi nadali (zwłaszcza w krajach zachodnich) rozpędu sprawiła, że o tematach seksu rozmawia się dzisiaj swobodniej i są bardziej obecne w przestrzeni publicznej.

Przeciętnemu Polakowi nieznane są szerzej dzieje polskiego ruchu hipisowskiego z końca lat 60 . i początku 70., uważanego przez niektórych za pierwszą opozycję antykomunistyczną, choć potem, w latach 80 ., w przeciwieństwie do czechosłowackich hipisów, ci polscy nie odegrali prawie żadnej roli w tworzeniu solidarnościowych struktur (Tarzan-Michalewski 1992, s. 100; Sipowicz 2015, s.180, 433). Historia polskich hipisów dobitnie jednak pokazuje jak działają państwa totalitarne, propaganda, czym reżimy różnią się od normalnych państw demokratycznych (Tracz 2014).

Poza faktografią i wiedzą czysto historyczną o burzliwych latach 60. i pokoleniu młodzieży, które jednak zmieniło świat (z czym niektórzy konserwatyści do tej pory nie mogą się pogodzić), opowieść o hipisach dostarcza wielu inspiracji na polu twórczości muzycznej, wizualnej, literackiej. Dla edukacji artystycznej te inspiracje są od dawna czytelne i oczywiste. Moda na hipisowskie lata 60. powraca zresztą co jakiś czas w modzie, muzyce, filmie, sztukach plastycznych.

Zgłębiając dzieje muzyki hipisowskiej, można dowiedzieć się, skąd wzięła się we współczesnej muzyce popularnej idea autentyczności, niezależności (undergroundu, alternatywy), otwartości na eksperymenty oraz improwizację, a także intelektualne teksty piosenek czy powszechne już dzisiaj w muzyce pop motywy orientalne. Współczesne wielkie koncerty nie istnieją praktycznie bez spektakularnej oprawy świetlnej (również z fragmentami filmów wyświetlanych dzisiaj na telebimach).

Śledząc dzieje ruchu hipisowskiego, można się też dowiedzieć, że to dzięki protoplastom hipisów - beatnikom - słuchamy dzisiaj nałogowo muzyki wklubach czy domowym zaciszu, a zgłębiając inspiracje literackie hipisów można np. poznać literaturę beatową, dowiedzieć się skąd się wziął motyw drogi, obecny nie tylko w muzyce rockowej (np. Route 66 The Rolling Stones, Highway 61 Revisted Dylana), ale także wielu filmach (Easy Rider, Bonnie i Clyde, Znikajacy punkt, Konwój, Dzikość serca - przywołując tylko te amerykańskie).

Elementy filozofii hipisowskiej pojawiają się w pedagogice krytycznej P. McLarena czy H. Giroux (McLaren 2015), wczesnej edukacji artystycznej (Gloton, Clero 
1985) oraz koncepcjach twórczości codziennej, będących elementem nauczania do twórczości czy - szerzej - pedagogiki twórczości (Szmidt 2013, s. 261-276).

Dzisiaj ideą przewodnią powszechnej edukacji oraz edukacji artystycznej w szkołach powszechnych jest egalitaryzm (bo w sumie czy da się inaczej?). Zachęca się uczniów do twórczości amatorskiej. I tutaj znowu można rzec, że idee te są starsze, bo sięgają czasów J. J. Rosseau. Hipisi sprawdzili je jednak w praktyce i otrzymali wyjątkowo ciekawe rezultaty, czego przykładem jest ich muzyka. Kto wie czy zaistniałaby potem punkowa dewiza DIY (Do It Yourself), która wielu młodych ludzi zachęciła do sięgnięcia po instrumenty i krzyczenia do mikrofonu o tym, co jest na świecie złe, co należy zmienić. Dla polskiego punk rocka, który $\mathrm{w}$ podziemiu tak otwarcie krytykował w latach 80 . system komunistyczny, takie dewizy okazały się szczególnie znaczące.

Kontakt z muzyką i przekazywaną w tekstach filozofią hipisowską ukazywał także potrzebę krytycznego nastawienia do wiedzy, ram i konwencji, stawiania na równi poznania zmysłowego i rozumowego czy kontestowania zastanej struktury społecznej. Właśnie w tych postawach można poszukiwać punktów stycznych z pedagogiką krytyczną, która - podobnie jak bardziej oczytani hipisi - odwoływała się do przedstawicieli szkoły frankfurckiej, zwłaszcza Herberta Marcuse’a oraz Ericha Fromma (Tracz 2014, s. 48-49; Sipowicz 2015, s. 80-86). W późniejszych latach kontrkultura hipisowska była także protestem przeciwko niedomogom amerykańskiej demokracji. Jest to już obszar edukacji obywatelskiej. Kontestacja przetarła drogę protestom przeciwko korupcji, hipokryzji polityków, łamaniu praw człowieka czy łamaniu konstytucyjnych zasad, dostarczając również niestety wzorców późniejszej działalności terrorystycznej. I tutaj także muzyka odegrała ważne miejsce w upowszechnianiu kontrkulturowych idei, o czym świadczą przywoływane utwory folkowe czy późniejszy Revolution Lennona.

Dla wielu młodych ludzi przygoda z hipizmem była Tolkienowską podróżą „tam i z powrotem”, z której powrócili dojrzalsi pod względem społecznym, duchowym, poznawczym czy nawet politycznym, mimo wcześniej deklarowanej apolityczności. Pomimo utopijnego charakteru wielu idei, najistotniejsze w twórczości hipisowskiej wydają się dzisiaj próby wyjścia „poza system”, ale nie po to, aby od niego uciec (bo to okazało się niemożliwe), ale po to, aby spojrzeć na niego inaczej i próbować go skutecznie przekształcać lub zmieniać.

\section{LITERATURA}

Balawender P., 2012, Próba kwasu w militarnej oranżadzie. „Trans/wizje”, nr 3, 119-122. Blumsztajn S., 2018, Strach i samotność. „Ale Historia Extra”, nr 1, 10-15. 
Brzozowicz G., 2016, Resortowe dziecko rock'n'rolla. Warszawa, Wydawnictwo Czerwone i Czarne.

Castaldo G., 1997, Ziemia obiecana: kultura rocka 1954-1994. Kraków, Wydawnictwo Znak.

Connell K., 1997, Opium as a Possible Influence on the Alice Books. opublikowano: http://www.victorianweb.org/authors/carroll/aiwl5.html [dostęp: 11.04.2018].

Dorobek A., 2016, Rock: problemy, sylwetki, konteksty. Szkice z estetyki i socjologii rocka. Chorzów, Wydawnictwo Medeia.

Echard W., 2017, Psychedelic Popular Music: A Historythrough Musical Topic Theory. Bloomington, Indiana University Press.

Eliade M., 1994, Szamanizm i archaiczne techniki ekstazy. Warszawa, Wydawnictwo Naukowe PWN.

Filipiak M., 2003, Od subkultury do kultury alternatywnej. Wprowadzenie do subkultur młodzieżowych. Lublin, Wydawnictwo UMCS.

Frith S., 1982, Sound Effects. Youth, Leisure, and the Politics ofRock'n'Roll. New York,PantheonBooks.

Garztecki M., 1978, Rock: od Presleya do Santany. Kraków, Polskie Wydawnictwo Muzyczne.

Gaszyński M., 2012, Cudowne lata: moja historia rock and rolla $w$ Polsce. Ożarów Mazowiecki, Wydawnictwo Olesiejuk.

Gloton R., Clero C., 1985, Twórcza aktywność dziecka. Warszawa, Wydawnictwa Szkolne i Pedagogiczne.

Gnoiński L., Skaradziński J., 2001, Encyklopedia polskiego rocka. Poznań, In Rock.

Goffman K., Joy D., 2005, Counterculture Through the Ages: From Abraham to Acid House. New York,Villard.

Gogola Z., 2012, Dzieje ruchu hipisowskiego. Kraków, Wydawnictwo OO. Franciszkanów „Bratni Zew”.

Grof S., 2014, Najdalsza podróż. Misterium i świadomość śmierci. Warszawa, Okultura. Hofmann A., 2016, LSD... moje trudne dziecko. Warszawa, Wydawnictwo „Cień Kryształu".

Idzikowska-Czubaj A., 2011, Rock w PRL-u. O paradoksach wspótistnienia. Poznań, Wydawnictwo Poznańskie.

Jankowski K., 1972, Hipisi w poszukiwaniu ziemi obiecanej. Warszawa, Książka i Wiedza. Jarniewicz J., 2016, All You Need Is Love. Sceny z życia kontrkultury. Kraków, Wydawnictwo Znak.

Jaśkiewicz T., Górka W., 2014, Byłem gitarzystą Niemena. Warszawa, Grupa Wydawnicza Foksal.

Jawłowska A., 1975, Drogi kontrkultury. Warszawa, Państwowy Instytut Wydawniczy. 
Krzan K., 2008, Ekstaza w wersji pop. Poszukiwania mistyczne w kulturze popularnej. Warszawa, Wydawnictwa Akademickie i Profesjonalne.

Kurowski B., 1992, Zdeptane kwiaty. Warszawa, Warszawska Oficyna Wydawnicza. Lundborg P., 2012, Psychedelia: An Ancient Culture, A Modern Way Of Life. Stockholm, Lysergia.

Macan E., 2001, Progresywny (u)rock. Toruń, C \& T.

McLaren P., 2015, Życie w szkołach. Wprowadzenie do pedagogiki krytycznej. Wrocław, Wydawnictwo Naukowe Dolnośląskiej Szkoły Wyższej.

Michalski D., 1990, Lekka muza: rock przez cały rok. Warszawa, Wiedza Powszechna.

Michalski D., 2014, Trzysta tysięcy gitar nam gra, czyli historia polskiej muzyki rozrywkowej (lata 1958-1973). Warszawa, Wydawnictwo Iskry.

Osęka P., 2018, Bunt studentów. „Polityka. Pomocnik Historyczny”, nr 1, 132-141.

Pęczak M., 2013, Subkultury w PRL. Opór, kreacja, imitacja. Warszawa, Narodowe Centrum Kultury (e-book).

Rychlewski M., 2011, Rewolucja rocka. Semiotyczne wymiary elektrycznej ekstazy. Gdańsk, Oficynka.

Schultes R. E., 1976, HallucinogenicPlants. New York,Golden Press.

Sipowicz K., 2015, Hipisi w PRL-u. Warszawa, Cyklady.

Storey J., 2003, Studia kulturowe i badania kultury popularnej. Teorie i metody. Kraków,

Wydawnictwo UJ.

Stuessy J., Lipscomb S., 2002, Rock and Roll: Its History and Stylistic Development. Upper Saddle River, New Jersey, Prentice Hall.

Surosz M., 2018, Krwawy koniec Praskiej Wiosny. „Ale Historia Extra”, nr 1, 56-61.

Szlendak K., 2012, Psychodeliczna eksplozja - krótka historia rocka psychodelicznego. „Trans/wizje”, nr 3, 105-109.

Tarzan-Michalewski W., 1992, Mistycy i narkomani. [Olsztyn], Wydawnictwo Ethos. Tolkien J.R.R., 1997, Hobbit, czyli tam i z powrotem. Warszawa, Wydawnictwo „Iskry”. Tracz B., 2014, Hippiesi, kudłacze, chwasty: Hipisi w Polsce w latach 1967-1975. Katowice, Kraków, Wydawnictwo Libron.

Turner S., 1997, Głód niebios: rock \& roll w poszukiwaniu zbawienia. Kraków, Wydawnictwo Znak.

Wrzesień W., 2013, Krótka historia młodzieżowej subkulturowości. Warszawa, Wydawnictwo Naukowe PWN.

ZyzdaB., 2015, Wolność i organizacja społeczeństwa $w$ doktrynie anarchizmu na przykładzie Wolnego Miasta Christiania. „Acta Erasmiana”, t. 9, 105-120. 


\title{
THERE AND BACK AGAIN - CURRENT COGNITIVE VALUES \\ OF THE HIPPIE MUSIC
}

\begin{abstract}
The aim of the article is a review of the musical output characterised as the "hippie one" in the context of its contemporary cognitive values. The retrospective of the bands, performers and pieces of music was preceded by a short description of the American and Polish hippie movement of the sixties and the seventies of the 20th century. The review of the selected examples of the musical creativity of that period was conducted paying special attention to their musical, textual, visual (album covers, stage performances) values, also quoting creators' profiles as well as the socio-cultural background of the epoch. In the conclusion the author made an attempt at shifting the distinguished values of the hippie music onto the educational ground with references to the contemporary artistic, civic education, as well as - critical pedagogy or didactics of creativity.
\end{abstract}

Keywords: music, rock, hippies, education 